\title{
Kandungan Senyawa Penangkal Sinar Ultra Violet dari Ekstrak Rumput Laut Eucheuma cottonii dan Turbinaria conoides
}

\author{
Rini Yanuarti ${ }^{1}$, Nurjanah ${ }^{1}$ Effionora Anwar ${ }^{2}$, Ginanjar Pratama ${ }^{3}$ \\ ${ }^{1}$ Departemen Teknologi Hasil Perairan, Fakultas Perikanan dan Ilmu Kelautan Institut Pertanian Bogor \\ 2 Departemen Farmasi Fakultas Farmasi Universitas Indonesia \\ ${ }^{3}$ Jurusan Teknologi Hasil Perikanan, Fakultas Ilmu Kelautan dan Perikanan, Universitas Maritim Raja Ali Haji \\ Email : riniy588@gmail.com
}

\begin{abstract}
Seaweed has several economic applications in various types of industries, one of them for the cosmetic industries. The most widely used cosmetics is for a sunscreen cream. The effectiveness of sunscreen cream is usually expressed by the SPF (Sun Protection Factor) value. The purpose of this research are to know the active compound content and SPF value on seaweed extract Turbinaria conoides and Eucheuma cottonii which can be used as active ingredient on sunscreen cream preparation. The results showed that the seaweed Turbinaria conoides contain class of phenol hydroquinone, flavonoid, triterpenoid, steroid, and saponin. The seaweed Eucheuma cottonii only found alkaloid compounds. The highest SPF values on seaweed Turbinaria conoides are present in methanol extract (SPF 16.7), meanwhile for seaweed Eucheuma cottonii is present in ethyl acetate extract (SPF 8.8). These results show that the extracts of seaweed Turbinaria conoides and Eucheuma cottonii have good potential when used as an active ingredient in sunscreen cream preparations.
\end{abstract}

Key Words :Eucheuma cottonii, sunscreen cream, SPF (Sun Protection Factor), Turbinaria conoides

\begin{abstract}
Abstrak
Rumput laut memiliki beberapa aplikasi ekonomi dalam berbagai jenis industri, salah satunya untuk industri kosmetik. Salah satu kosmetik yang banyak digunakan yaitu krim tabir surya. Efektivitas dari krim tabir surya biasanya dinyatakan dengan nilai SPF (Sun Protection Factor). Tujuan dari penelitian ini adalah untuk mengetahui kandungan senyawa aktif dan nilai SPF pada ekstrak rumput laut Turbinaria conoides dan Eucheuma cottonii yang dapat digunakan sebagai bahan aktif pada sediaan krim tabir surya. Hasil pengujian menunjukkan rumput laut Turbinaria conoides mengandung golongan senyawa fenol hidrokuinon, flavonoid, triterpenoid, steroid, dan saponin. Rumput laut Eucheuma cottonii hanya ditemukan senyawa alkaloid. Nilai SPF tertinggi pada rumput laut Turbinaria conoides terdapat pada ekstrak metanol (SPF 16.7), sedangkan untuk rumput laut Eucheuma cottonii terdapat pada ekstrak etil asetat (SPF 8.8). Hasil tersebut memperlihatkan bahwa ekstrak dari rumput laut Turbinaria conoides dan Eucheuma cottonii memiliki potensi yang baik jika digunakan sebagai bahan aktif pada sediaan krim tabir surya.
\end{abstract}

Kata kunci :Eucheuma cottonii, krim tabir surya,SPF (Sun Protection Factor), Turbinaria conoides.

\section{Pendahuluan}

Rumput laut merupakan tumbuhan laut yang tidak dapat dibedakan antara akar, batang dan daun, sehingga seluruh tubuhnya disebut thallus. Rumput laut dibedakan menjadi tiga kelas berdasarkan kandungan pigmen yang terdapat dalam thallus yaitu; kelas Chlorophyceae, Rhodophyceae dan Phaeophyceae. Ketiga kelas rumput laut tersebut bernilai ekonomis penting karena kandungan senyawa kimianya (Soenardjo, 2011).

Rumput laut yang memiliki nilai ekonomis serta peluang yang besar untuk dikembangkan sebagai bahan kosmetik salah satunya yaitu Eucheuma cottonii. Pemanfaatan E. cottonii bukan hanya terbatas sebagai bahan pangan saja, melainkan sudah banyak olahan dari rumput laut ini yaitu karagenan. Ekstrak karagenan merupakan bahan baku dalam bidang industri, kedokteran, farmasi dan kosmetik. Rumput laut $E$. cottonii dipanen saat umur 45 - 60 hari setelah waktu tanam. Jika $E$. cottonii dipanen lebih cepat maka kandungan karagenan serta kekuatan gel yang dihasilkan rendah (Anggadiredja et al., 2006).

Rumput laut Turbinaria sp. merupakan rumput laut dengan jumlah spesies yang sangat sedikit yaitu hanya terdapat 17 spesies. Spesies rumput laut seperti $T$. conoides, $T$. ornata dan $T$. decurent, merupakan jenis rumput laut coklat yang banyak ditemukan di perairan Indonesia (Wynne 2002). Rumput laut $T$. conoides merupakan salah satu jenis rumput laut coklat yang keberadaannya belum termanfaatkan secara optimal (Willams, 2007). Rumput laut $T$. conoides memiliki manfaat dibidang kesehatan, mikrobiologi, enzimologi dan ekotoksikologi (La Barre et al., 2010). Rumput laut $T$. conoides menghasilkan alginat yang banyak digunakan dalam industri untuk memperkuat tekstur dan stabilitas produk. Rumput laut $T$. conoides memiliki beberapa aplikasi ekonomi dalam berbagai jenis industri, salah satunya untuk industri kosmetik (Hafting et al., 2015). 
Rumput laut secara umum memiliki kemampuan sebagai antioksidan, imunostimulan dan aktivitas antibakteri (Selim 2012). Rumput laut $T$. conoides mengandung zat bioaktif polifenol, florotanin dan senyawa tanin (Hermund et al., 2016). Senyawa bioaktif seperti fenol hidrokuinon, flavonoid dan triterpenoid yang ditemukan pada rumput laut sangat prospektif untuk digunakan pada sediaan kosmetik (Nurjanah et al., 2016). Rumput laut $T$. conoides menunjukkan aktivitas antioksidan paling tinggi dari jenis rumput laut lainnya (Budhiyanti et al., 2012). Rumput laut $E$. cottonii bisa diformulasikan dalam krim anti-aging dan facial creams (Campo et al., 2009), skin lotion (Putri et al., 2015), pasta gigi, tonik rambut, dan penstabil pada sabun ( $\mathrm{Li}$ et al., 2014), serta krim tabir surya (Luthfiyana et al., 2016).

Kulit merupakan bagian yang menutupi permukaan tubuh dan memiliki fungsi sebagai pelindung dari sinar ultraviolet. Sinar ultraviolet dari matahari dapat merusak kulit seperti kemerahan, pendarahan, penuaan dan meningkatkan risiko kanker kulit (Lann et al. 2016). Agustin et al. (2013) menyatakan kulit memiliki sistem perlindungan alami terhadap efek sinar matahari, tetapi tidak efektif untuk menahan paparan sinar matahari yang berlebih, oleh karena itu diperlukan pelindung tambahan menggunakan krim tabir surya.

Salah satu produk kosmetik yang banyak digunakan yaitu krim tabir surya. Efektivitas dari krim tabir surya biasanya dinyatakan dengan nilai SPF (Sun Protection Factor). Nilai SPF semakin besar maka semakin besar perlindungan yang diberikan oleh produk krim tabir surya tersebut (Wilkinson dan Moore,1982). Senyawa bahan alam yang sudah dimanfaatkan sebagai agen pelindung dari sinar ultraviolet yaitu Vitamin C, Vitamin E dan $\beta$-karoten. Svobodova et al. (2003) menyatakan senyawa bioaktif fenolik dapat berperan sebagai bahan aktif sediaan krim tabir surya dan dapat meningkatkan nilai SPF pada krim tabir surya. Besarnya peluang pemanfaatan rumput laut sebagai bahan aktif pada kosmetik berupa hasil ektraksi dari rumput laut $T$. conoides dan E. cottonii dan ini belum dioptimalkan. Maka diperlukan penelitian ini untuk mengetahui kandungan senyawa aktif dan nilai SPF pada ekstrak rumput laut $T$. conoides dan $E$. cottonii. Hasil ekstaksinya dapat digunakan sebagai bahan aktif pada sediaan krim tabir surya.

\section{Metode}

\section{Bahan dan Alat}

Bahan utama yang digunakan dalam penelitian adalah rumput laut $T$. conoides dan rumput laut $E$. cottonii. Bahan lain yang digunakan yaitu metanol p.a (Merck), etanol p.a (Merck), nheksan p.a (Merck).
Alat yang digunakan dalam penelitian antara lain blender (Philips HR 2115 blender tango plastik), vorteks (Stuart SA8 vortex mixer, $230 \mathrm{~V}, \quad 50-60 \mathrm{~Hz}, 20-2500 \mathrm{rpm})$, rotary evaporator (Heidolph instrument laborota 4000), spektrofotometer UV-Vis (U-2800 hitachi), orbital shaker (Wise shaker), timbangan analitik (Merek sartorius), tabung reaksi, batang pengaduk, lempeng tetes, pipet tetes, pinggan porselen, dan gelas beker.

\section{Pengambilan sampel}

Rumput laut $T$. conoides diambil secara langsung dari Perairan Pasauran Desa Umbul Tanjung Kecamatan Cinangka Kabupaten Serang-Banten. Rumput laut merah E. cottonii merupakan hasil budidaya di Perairan Lontar, kecamatan Tirtayasa Kabupaten Serang-Banten. Rumput laut dicuci menggunakan air laut untuk menghilangkan kotorandan pasir, kemudian dikeringkan di tempat yang terlindung dari sinar matahari secara langsung (Masduqi et al., 2014). Diagram alir proses pengujian dapat dilihat pada Gambar 1.

\section{Analisis proksimat}

Analisis proksimat bertujuan untuk mengetahui komponen awal yang terdapat pada rumput laut $T$. conoides dan $E$. cottonii segar. Kadar karbohidrat diperoleh melalui perhitungan by difference. Analisis kadar proksimat adalah analisis yang dilakukan untuk memprediksi komposisis kimia suatu bahan termasuk didalamnya analisis kandungan air, lemak, abu dan protein (AOAC, 2005).

\section{Analisis fitokimia}

Analisis fitokimia merupakan analisis kualitatif yang dilakukan untuk mengetahui komponen bioaktif yang terkandung dalam rumput laut. Analisis fitokimia yang dilakukan meliputi uji alkaloid, fenol hidrokuinon, flavonoid, triterpenoid, steroid, tanin, dan saponin (Harborne, 1987).

\section{Ekstraksi senyawa bioaktif}

Ekstraksi rumput laut dilakukan
menggunakan metode maserasi bertingkat. Metode ini digunakan karena cocok untuk bahan yang tidak tahan terhadap pemanasan. Maserasi pertama dilakukan dengan pelarut non-polar ( $\mathrm{n}$ heksan), semi polar (etil asetat) dan polar (metanol). Rumput laut dihaluskan dan dimaserasi dengan perbandingan (1:5b/v), kemudian dikocok menggunakan orbital shaker $(150 \mathrm{rpm})$ selama $3 \times 24$ jam, selanjutnya disaring dengan kertas Whatman 42 sehinggadidapatkan filtrat dan residu. Filtrat dari ketiga pelarut tersebut dievaporasi menggunakan rotary vacuum evaporator pada suhu $40^{\circ} \mathrm{C}$ (Widyasanti et al., 2016). Ekstrak yang diperoleh dihitung dengan rumus sebagai berikut : 
Berat ekstrak $=($ berat cawan + ekstrak $)-($ berat cawan kosong)

Rendemen dari ekstrak dihitung berdasarkan Rendemen $=\frac{\text { berat ekstrak }}{\text { berat sampel }} \times 100 \%$ persamaan :

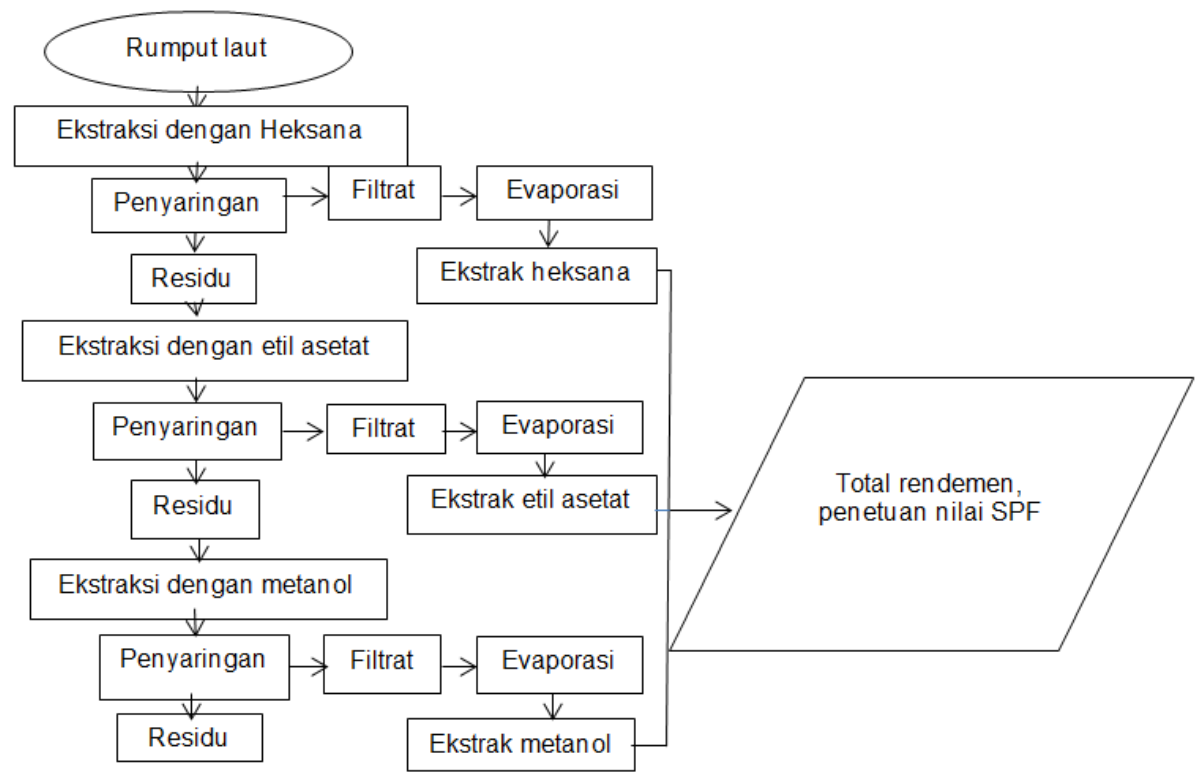

Gambar 1. Diagram alir proses pengujian rumputl laut T. conoides dan E. cottonii (Yanuarti et al. 2017)

\section{Analisis nilai SPF}

Penentuan efektifitas tabir surya dilakukan dengan menentukan nilai SPF menggunakan alat spektrofotometer UV-Vis.Sampel sebanyak 400 mg dilarutkan dalam etanol $25 \mathrm{~mL}$ hingga homogen. Kurva serapan uji yang digunakan dengan panjang gelombang 290-320 nm, kemudian tetapkan serapan rata-rata (Ar) dengan interval $10 \mathrm{~nm}$ dengan tiga kali pengulangan (Mokodompit et al., 2013).Nilai EE x I adalah konstan, yang nilainya sudah ditetapkan oleh Sayre et al., 1979. Data nilai tersebut dapat dilihat pada Tabel 1.

Tabel 1. Efektivitas sediaan krim tabir surya berdasarkan nilai SPF

\begin{tabular}{cl}
\hline SPF & $\begin{array}{l}\text { Kategori Proteksi } \\
\text { Tabir Surya }\end{array}$ \\
\hline $2-4$ & Proteksi minimal \\
$4-6$ & Proteksi sedang \\
$6-8$ & Proteksi ekstra \\
$8-15$ & Proteksi maksimal \\
$\geq 15$ & Proteksi ultra \\
\hline
\end{tabular}

Data yang didapatkan diolah menggunakan persamaan Mansur (Dutra et al.,2004).

$\operatorname{SPF}=C F x \sum_{290}^{320} E E(\lambda) \times I(\lambda) x \operatorname{abs}(\lambda)$

Keterangan :

CF $\quad=$ faktor koreksi

EE = spektrum efek erytermal

I = spektrum intensitas dari matahari

Abs = absorban dari sampel

\section{Hasil dan Pembahasan}

\section{Kadar proksimat rumput laut}

Hasil pengujian kandar proksimat pada rumput laut $T$. conoides dan $E$. cottonii segar dapat dilihat pada Tabel 2.

Tabel 2. Proksimat rumput laut T. conoides dan E. Cottonii

\begin{tabular}{cccccc}
\hline \multicolumn{5}{c}{ Komposisi Kimia } \\
\hline Air (\%) & Abu (\%) & Protein (\%) & Lemak (\%) & $\begin{array}{c}\text { Karbohidrat (by } \\
\text { difference) }\end{array}$ & Rumput laut \\
\hline $84,42 \pm 0,51$ & $2,15 \pm 0,16$ & $3,86 \pm 0,09$ & $0,47 \pm 0,01$ & $9,1 \pm 0,12$ & T. conoides \\
\hline $93,04 \pm 0,51$ & $2,34 \pm 0,05$ & $1,02 \pm 0,23$ & $0,58 \pm 0,09$ & $3,02 \pm 0,80$ & E. cottonii \\
\hline
\end{tabular}


Senyawa aktif rumput laut $T$. conoides dan $E$. cottonii

Analisis fitokimia merupakan uji kualitatif yang dilakukan pada simplisia rumput laut untuk mengetahui golongan senyawa aktif seperti, alkaloid, fenol hidrokuinon, flavonoid, triterpenoid, steroid, tanin dan saponin. Hasil pengujian menunjukkan rumput laut $T$. conoides mengandung golongan senyawa fenol hidrokuinon, flavonoid, triterpenoid, steroid, dan saponin. Rumput laut E. cottonii hanya ditemukan senyawa alkaloid. Hasil analisis fitokimia pada rumput laut $T$. conoides dan E. cottonii dapat dilihat pada Tabel 3.

Tabel 3. Hasil uji fitokimia pada $T$. conoides dan E. cottonii

\begin{tabular}{lcc}
\hline \multicolumn{1}{c}{ Jenis uji } & \multicolumn{2}{c}{ Hasil } \\
\cline { 2 - 3 } fitokimia & T. conoides & E. cottonii \\
\hline Alkaloid : & & \\
- Meyer & - & + \\
- Wagner & - & + \\
- Dragendrof & - & + \\
Fenol & + & - \\
hidrokuinon & + & - \\
Flavonoid & + & - \\
Triterpenoid & + & - \\
Steroid & - & - \\
Tanin & + & - \\
Saponin & &
\end{tabular}

Ekstrak rumput laut $T$. conoides dan $E$. cottonii

Rumput laut $T$. conoides dan E. cottonii yang telah di ekstrak dengan tiga pelarut yaitu, $\mathrm{n}-$ heksan, etil asetat dan metanol menghasilkan rendemen yang dapat dilihat pada Tabel 4 dan Tabel 5.

Tabel 4. Rendemen ekstrak $n-h e k s a n$, etil asetat dan metanol $T$. conoides

\begin{tabular}{|c|c|c|c|}
\hline \multirow[b]{2}{*}{ Sampel } & \multicolumn{2}{|c|}{ Massa $(\mathrm{g})$} & \multirow[b]{2}{*}{$\begin{array}{c}\text { Rendemen } \\
(\%)\end{array}$} \\
\hline & $\begin{array}{l}\text { Berat } \\
\text { sampel }\end{array}$ & $\begin{array}{l}\text { Berat } \\
\text { ekstrak }\end{array}$ & \\
\hline $\begin{array}{l}\text { Ekstrak } \\
\text { n-eksan }\end{array}$ & 200 & 0,36 & 0,18 \\
\hline $\begin{array}{l}\text { Ekstrak } \\
\text { etil } \\
\text { asetat }\end{array}$ & 200 & 0,75 & 0,37 \\
\hline $\begin{array}{l}\text { Ekstrak } \\
\text { metanol }\end{array}$ & 200 & 16,35 & 8,17 \\
\hline & Total Ren & & 8,72 \\
\hline
\end{tabular}

Tabel 5. Rendemen ekstrak n-heksan, etil asetat dan metanol E. Cottonii

\begin{tabular}{lccc}
\hline Sampel & \multicolumn{2}{c}{ Massa (g) } & Berat \\
& sampel & $\begin{array}{c}\text { Berat } \\
\text { ekstrak }\end{array}$ & $\begin{array}{c}\text { Rendemen } \\
(\%)\end{array}$ \\
\hline $\begin{array}{l}\text { Ekstrak } \\
\text { n-eksan }\end{array}$ & 200 & 0,40 & 0,20 \\
$\begin{array}{l}\text { Ekstrak } \\
\text { etil }\end{array}$ & 200 & 0,28 & 0,14 \\
$\begin{array}{l}\text { asetat } \\
\text { Ekstrak } \\
\text { metanol }\end{array}$ & 200 & 18,66 & 9,33 \\
\hline \multicolumn{5}{r}{ Total Rendemen } & 9,67 \\
\hline
\end{tabular}

\section{Nilai SPF (Sun Protection Factor) ekstrak rumput laut}

Nilai SPF sudah menjadi standar di seluruh dunia untuk mengukur efektivitas krim tabir surya. Nilai tersebut menunjukkan berapa lama seseorang dapat bertahan di bawah sinar matahari. Hasil pengukuran SPF pada ekstrak rumput laut $T$. conoides dan $E$. cottonii dapat dilihat pada Tabel 6.

Tabel 6. Nilai SPF pada ekstrak $T$. conoides dan E. Cottonii

\begin{tabular}{lc}
\hline \multicolumn{1}{c}{ Sampel uji } & $\begin{array}{c}\text { Nilai SPF yang } \\
\text { didapatkan }\end{array}$ \\
\hline 1. Turbinaria conoides & \\
Ekstrak n-heksan & $5,2 \pm 0,02$ \\
Ekstrak etil asetat & $13,3 \pm 0,01$ \\
Ekstrak metanol & $16,7 \pm 0,05$ \\
2. Eucheuma cottonii & \\
Ekstrak n-heksan & $5,9 \pm 0,02$ \\
Ekstrak etil asetat & $8,8 \pm 0,03$ \\
Ekstrak metanol & $6,7 \pm 0,02$ \\
\hline
\end{tabular}

Air merupakan salah satu komponen penting dalam suatu bahan. Kadar air yang didapatkan pada $T$. conoides lebih rendah dibandingkan dengan Santoso et al. (2002) yang mendapatkan kadar air pada $T$. conoides sebesar 85.05\%. Kadar air pada E. cottonii sebesar 93.04\%, kadar tersebut lebih tinggi dibandingkan dengan Sari et al. (2015) yang mendapatkan kadar air sebesar 92,97\%. Kadar air yang didapatkan cukup tinggi karena rumput laut yang diuji merupakan rumput laut segar. Abas (2006) menyatakan perbedaan kadar air dalam suatu bahan ditentukan oleh kondisi lingkungan, penyimpanan, suhu dan kelembaban.

Kadar abu merupakan komponen yang penting dalam suatu bahan untuk menentukan kadar mineral. Hasil pengabuan $T$. conoides lebih rendah dibandingkan dengan Santoso et al. (2002) yang mendapatkan kadar abu sebesar $2,5 \%$. Kadar abu pada E. cottonii sebesar $2,34 \%$, 
nilai tersebut lebih rendah dibandingkan dengan Sanger (2010) sebesar 4,0\%. Rumput laut secara umum mengandung kadar abu hingga 36\%. Tinggi rendahnya kadar abu pada rumput laut dipengaruhi oleh cara penyerapan hara mineral. Proses penyerapan hara mineral pada rumput laut melalui seluruh permukaan thallus, sehingga penyerapannya lebih efektif. Banyaknya hara mineral yang diserap akan mempengaruhi kadar abu pada jaringan rumput laut (Handayani et al., 2004)

Kadar protein dalam suatu bahan sangat menentukan kualitas dari bahan tersebut. Kadar protein pada $T$. conoides lebih rendah dibandingkan dengan Renaud dan Luong-Van (2007) dan Marquez et al., (2014) yang memperoleh kadar protein masing-masing sebesar 5,9\% dan 8,6\%. Kadar protein yang didapatkan pada penelitian ini termasuk kategori yang baik, karena rumput laut coklat mengandung protein sebesar 3-9\% dari berat basah (Burtin 2003). Kadar protein yang ada pada E. cottonii lebih rendah dibandingkan dengan Daud (2013) yang mendapatkan kadar protein sebesar 2,46$3,29 \%$. Kadar protein pada suatu bahan dapat bervariasi tergantung dengan spesies, area geografis, musim atau kondisi lingkungan perairan (Balboa et al., 2015).

Kadar lemak yang didapatkan pada penelitian ini lebih rendah jika dibandingkan dengan Narasimman dan Murugaiyan (2012); Manivannan et al. (2008); Renaud dan LuongVan (2007), yang mendapatkan kadar lemak masing-masing sebesar 3,0\%; 1,9\%; dan 3,3\%. Kadar lemak yang ada pada E. cottonii setara dengan Liem (2013) yang mendapatkan kadar lemak sebesar 0,53-1,34\%. Rendahnya kandungan lemak yang didapatkan karena rumput laut dan tanaman pada umumnya menyimpan cadangan makanan dalam bentuk karbohidrat terutama polisakarida. Hal itu berbeda dengan hewan yang menyimpan cadangan makanan dalam jaringan lemak. Perbedaan bentuk penyimpanan tersebut menyebabkan lemak nabati memiliki kandungan yang lebih rendah jika dibandingkan dengan lemak hewani. Perbedaan kandungan proksimat pada rumput laut dipengaruhi oleh beberapa faktor seperti proses pengambilan sampel, waktu pengambilan, dan faktor lingkungan seperti suhu, salinitas, dan ke dalaman (Rasyid, 2002).

\section{Senyawa aktif rumput laut $T$. conoides dan $E$.} cottonii

Komponen bioaktif seperti fenol hidrokuinon, flavonoid, dan triterpenoid diduga memiliki potensi sebagai bahan krim tabir surya (Nurjanah et al., 2015). Hasil penelitian menunjukkan $T$. conoides positif mengandung fenol hidrokuinon. Senyawa fenol cenderung mudah larut dalam air karena umumnya seyawa ini berikatan dengan gula sebagai glikosida dan biasanya terdapat dalam vakuola sel (Harborne, 1987). Yanuarti et al., (2017) melaporkan $T$. Conoides yang diekstrak dengan etil asetat memiliki total fenol lebih tinggi $(211,00 \mathrm{mg} \mathrm{GAE} / \mathrm{g})$ dibandingkan ekstrak metanol (195,44 mg $\mathrm{GAE} / \mathrm{g}$ ).

Kandungan flavonoid pada $T$. conoides menunjukkan hasil positif dengan terbentuknya lapisan amil coklat kuat. Rumput laut direaksikan dengan serbuk $\mathrm{Mg}$ yang berperan dalam mereduksi agar ikatan gula pecah sehingga mudah ditarik oleh amil alkohol. Yanuarti et al. (2017) melaporkan T. conoides yang diekstrak dengan etil asetat memiliki total flavonoid lebih tinggi $(157,16 \mathrm{mg}$ QE/g) dibandingkan ekstrak metanol (17,36 mg QE/g). Senyawa flavonoid memiliki bagian yang bersifat polar maupun non polar. Secara umum flavonoid memiliki efek antihipertensi dan dapat mencegah pendarahan pada kulit (Septiana dan Asnani, 2012).

Kandungan triterpenoid pada $T$. conoides menunjukkan hasil yang positif dengan terbentuknya warna kemerahan. Prinsip ini berdasarkan kemampuan senyawa triterpenoid membentuk warna jika direaksikan dengan $\mathrm{H}_{2} \mathrm{SO}_{4}$ pekat. Triterpenoid merupakan salah satu senyawa yang berpotensi sebagai antioksidan, biasanya larut dalam pelarut non-polar (Sangi et al., 2008). Seenivasan et al. (2012) menyatakan kandungan senyawa fitokimia dari rumput laut secara luas digunakan dalam berbagai industri seperti makanan, tekstil, dan farmasi. Rumput laut menghasilkan berbagai macam senyawa metabolit sekunder yang memiliki fungsi sebagai antijamur, antibakteri, antivirus dan antioksidan (Newman et al., 2003).

\section{Ekstrak rumput laut ( $T$. conoides dan $E$. cottonii)}

Rendemen tertinggi terdapat pada rumput laut yang di ekstrak dengan metanol. Hasil tersebut menunjukkan bahwa komponen yang terkandung dalam $T$. conoides dan E. cottonii lebih banyak terlarut dalam pelarut polar dibandingkan dengan pelarut semi dan non-polar. Senyawa yang bersifat polar larut dalam pelarut polar seperti metanol dan sebaliknya. Tingginya rendemen yang terdapat pada pelarut metanol menunjukkan pelarut tersebut mampu mengekstrak lebih banyak komponen bioaktif yang memiliki sifat kepolaran yang lebih tinggi. Pelarut metanol dapat merusak dinding sel pada suatu bahan sehingga senyawa yang bersifat polar atau non-polar dapat terlarut dalam metanol. Khopkar (2008) menyatakan tingginya rendemen yang diperoleh dari suatu tumbuhan yang di ekstrak dipengaruhi oleh beberapa faktor seperti jenis pelarut yang digunakan untuk mengekstrak komponen dari tumbuhan tersebut, kondisi dan waktu penyimpanan, lama waktu ekstraksi dan 
perbandingan jumlah sampel terhadap jumlah pelarut yang digunakan.

\section{Nilai SPF (Sun Protection Factor) ekstrak rumput laut}

Menurut Walters et al. (1997) efektivitas sebuah krim tabir surya dinyatakan oleh Sun Protection Factor (SPF), yang didefinisikan sebagai perbandingan Dosis Eritema Minimum (DEM) pada kulit manusia terlindungi tabir surya dengan DEM tanpa perlindungan. DEM adalah nilai yang menunjukkan sensitivitas akut individu terhadap sinar ultraviolet. DEM ini menunjukkan jumlah minimal sinar ultraviolet yang dibutuhkan untuk menimbulkan kemerahan ketika seseorang terpapar sinar ultraviolet (Mitsui 1997). Kategori kemampuan krim tabir surya menurut Damogalad et al. (2013) adalah proteksi minimal (2-4), proteksi sedang (4-6), proteksi ekstra (6-8), proteksi maksimal (8-15), dan proteksi ultra (>15).

Hasil penelitian menunjukan nilai SPF tertinggi pada rumput laut $T$. conoides terdapat pada ekstrak metanol (SPF 16,7), sedangkan untuk rumput laut $E$. cottonii terdapat pada ekstrak etil asetat (SPF 8,8). Berdasarkan data tersebut dapat dinyatakan setiap pelarut memiliki karakteristik nilai SPF yang berbeda. Ektrak metanol $T$. conoides memiliki kategori kemampuan proteksi ultra, sedangkan ekstrak etil asetat $E$. cottonii memiliki kategori kemampuan proteksi maksimal.

Kandungan SPF banyak ditemukan pada sampel yang bersifat semi polar dan polar, pada umumnya terdapat pada sumber nabati seperti rumput laut. Malsawmtluangi et al., (2013), menyatakan ekstrak dari suatu bahan memiliki potensi dalam mengatasi proses karsinogenesis

\section{Daftar Referensi}

[AOAC] Association of Official Analytical Chemist., 2005. Official Methods of Analysis. $18^{\text {th }} \mathrm{Ed}$. Mayland (US): Association of Official Analytic Chemist Inc.

Abbas, A., 2006. Minuman fungsional berbahan dasar teh dan kayu manis untuk penderita diabetes. Prosiding Seminar Nasional Iptek. Hal 91-98.

Agustin R, Oktadefitri Y, Lucida H. 2013. Formulasi krim tabir surya dari kombinasi etil p-metoksisinamat dengan katekin. Prosiding Seminar Nasional Perkembangan Terkini Sains Farmasi dan Klinik III. 184-198.

Anggadiredja, J.T., Zatnika, A., Purwoto,H., Istini,S., 2006. Rumput Laut.Jakarta. Penebar Swadaya. dan memiliki kemampuan dalam melindungi kulit dari sinar ultraviolet. Efek merugikan yang ditimbulkan oleh radiasi ultraviolet pada kulit adalah terjadinya kerusakan epidermis, pigmentasi, pengkerutan, penuaan dini dan dalam waktu yang lama dapat mengakibatkan kanker.

Nilai SPF yang tinggi menunjukkan keefektifan produk dalam menangkal paparan sinar ultraviolet terhadap kulit. Kandungan fenol hidrokuinon, flavonoid dan triterpenoid yang ditemukan pada rumput laut $T$. conoides diduga bekerja sebagai bahan aktif pada krim tabir surya. Menurut Damogalad et. al. (2013) flavonoid sebagai antioksidan yang kuat dan dapat mengikat ion logam yang mampu mencegah efek berbahaya dari paparan sinar ultaviolet. Saewan dan Jimtaisong (2013) menyatakan senyawa flavonoid yang ditemukan pada rumput laut dapt melindungi tanaman dari paparan radiasi sinar ultraviolet. Menurut Wolf et al. (2001) senyawa fenolik khususnya golongan flavonoid mempunyai potensi sebagai tabir surya karena adanya gugus kromofor yang mampu menyerap sinar ultaviolet sehingga mengurangi intensitasnya pada kulit.

\section{Simpulan}

Hasil penelitian ini memperlihatkan bahwa ekstrak dari rumput laut $T$. conoides dan $E$. cottonii memiliki potensi yang baik jika digunakan sebagai bahan aktif pada sediaan krim tabir surya karena memiliki nilai SPF yang tinggi, selain itu rumput laut tersebut memiliki senyawa bioaktif seperti fenol hidrokuinon, flavonoid, dan triterpenoid yang potensial untuk digunakan pada sediaan krim tabir surya.

Balboa, E.M., Gallego-Fabrega, C., Moure, A., 2015. Study of the seasional variation on proximate composition of oven-dried Sargassummuticum biomass collected in Vigo Ria, Spain. Journal Applied Phycology. 13(5):488-495.

Budhiyanti, S.A., Raharjo, S., Djagal, W., Marseno, Lelana, I.Y.B., 2012. Antioxidant activity of brown algae Sargassum species extract from the coastline of Java Island. American Journal of Agricultural and Biological Sciences. 7(3): 337-346.

Burtin, P., 2003. Nutritional value of seaweed. Journal of Agricultural Food Chemistry. 2(4):1-6.

Campo, V.L., Kawano, D.F., Silva, J.D.B., Ivone, C.I., 2009. Carrageenans: biological properties, chemical modifications and structural analysis. Carbohydrate Polymers. 77:167-180. 
Damogalad, V., Edy, HJ., Supriati, HS., 2013. Formulasi krim tabir surya ekstrak kulit nanas (Ananas comosus L. Merr) dan uji in vitro nilai sun protecting factor (SPF). Pharmacon. Jurnal IImiah Farmasi UNSRAT. 2(2): 12-16.

Daud, R., 2013. Pengaruh masa tanam terhadap kualitas rumput laut, Kappaphycus alvarezii. Media Akuakultur. 8(2):135-138.

Dutra, E.A., Oliveira, D.A., Kedor-Hackman, Santoro, M.I., 2004. Determination of sun protection factor (SPF) of sunscreens by ultraviolet spectrophotometry. Brazilian Journal of Pharmaceutical Sciences. 40(3):381-385.

Handayani, T., Sutarno, Setyawan, A.D., 2004. Analisis komposisi nutrisi rumput laut Sargassum crassifolium J.Agardh. Jurnal Biofarmasi. 2(2):45-52.

Harborne,J.,1996. Metode Fitokimia: Penuntun Cara Modern Menganalisis Tumbuhan. Cetakan kedua. Penerjemah: Padmawinata, K. dan I. Soediro. Bandung: Penerbit ITB.

Hafting, J.T., Craigie, J.S., Stengel, D.B., Loureiro, R.R., Buschmann, A. H, Yarish, C., Edwards, M.D., Critchley, A.T. 2015. Prospects and challenges for industrial production of seaweed bioactives. Journal Phycological. 51:821-837.

Hermund, D.B., Karadag, A., Andersen, U., Jonsdottir, R., Kristinsson, H.G., Alasarval, C., Jacobsen, C., 2016. Oxidative stability of granola bars enriched with multilayered fish oil emulsion in the presence of novel brown seaweed based antioxidants. Journal of Agricultural and Food Chemistry. 64(44):8359-8368.

Khopkar, S.M,. 2008.Konsep Dasar kimia Analitik. Jakarta.UI Press.

La Barre, S.P., Potin, C., Leblanc, Delage., 2010. The halogenated metabolism of brown algae (phaeophyta), its biological importance and its environmental significance.Marine Drugs. 8:988-1010.

Lann KL, Surget G, Couteau C, Coiffard L, Cerantola S, Gaillard F, Larnicol M, Zubia M, Guerard F, Poupart N, Pouvreau VS. 2016. Sunscreen, antioxidant, and bactericide capacities of phlorotannins from the brown macroalga Halidrys siliquosa. Journal of Applied Phycology. 28:3547-3550.

Li, L., Ni, R., Shao, Y., Mao, S., 2014. Carrageenan and its applications in drug delivery. Journal Carbohydrate Polymers. 103:1-11.

Liem, Z.A., 2013. Kandungan proksimat dan aktivitas antioksidan rumput laut merah (Eucheuma cottonii) di perairan Kupang Barat [tesis]. Salatiga: Universitas Kristen Satya Wacana.

Luthfiyana, N., Nurjanah, Nurimala, M., Anwar, E., Hidayat, T., 2016. Rasio bubur rumput laut Eucheuma cottonii dan Sargassum sp. sebagai formula krim tabir surya. Jurnal Pengolahan hasil Perikanan Indonesia.19(3):183-195.

Malsawmtluangi, C., Nath, D.K., Jamatia, I., Lianhimgthangi, Zarzoliana, E., Pachuau, L., 2016. Determination of sun protection factor (SPF) number of some aqueous herbal extracts. Journal of Applied Pharmaceutical Science. 3(9):150-151.

Manivannan, K., Thirumaran, G., Karthikai, D.G., Hemalatha, A., Anantharaman, P., 2008. Biochemical composition of seaweeds from Mandapam Coastal Regions along Southeast Coast of India. AmericanEurasian Journal of Botany. 1(2):32-37.

Marquez, G.P.B., Santianez, W.J.E., Trajono, G.C., Montano, N.E., Araki, H., Takeuchi, H., Hasegawa, T., 2014. Seaweed biomass of the Philippines: sustainable feedstock for biogas production. Journal Renewable and Sustainable Energy Reviews.38:10561068.

Masduqi, A.F., Izzati, M., Prihastanti, E., 2014. Efek metode pengeringan terhadap kandungan bahan kimia dalam rumput laut Sargassum polycystum.Buletin Anatomi dan Fisiologi. 22(1):1-9.

Mitsui., 1997. New Cosmetic Science. New York (US): Elsevier

Mokodompit, A.N, dy, H.J., Wiyono, W., 2013. Penentuan nilai sun protective factor (SPF) secara in vitro krim tabir surya ekstrak etanol kulit alpukat. Jurnal IImiah Farmasi pharmacon. 2(03):83-85.

Narasimman, S., Murugaiyan, K., 2012. Proximate composition of certain selected marine macro-algae from Mandapan Coastal Region (Gulf of Mannar), Southeast Coast of Tamil Nadu. International Journal Pharmaceutical Biology Archaelogy. 3:918939.

Newman, D.J., Cragg, G.M., Snader, K.M.,2003. Natural products as source of new drugs over the period 1981-2002. Journal of Natural Products. 66(7):1022-1037. 
Nurjanah, Nurilmala, N., Anwar, E., Luthfiyana, N., 2015. Identification of bioactive compounds seaweed as raw sunscreen cream. The 2 nd International Symposium on Aquatic Products Processing and Health [ISAPROSH].

Nurjanah, Nurimala, M., Hidayat, T., Sudirdjo, F., 2016. Characteristics of seaweed as raw materials for cosmetics. Aquatic Procedia. 7:177-180.

Putri, R.R., Herpandi, Nopianti, R., 2015. Karakteristik fisiko-kimia dan mutu sensori skin lotion rumput laut (Eucheuma cottonii) dengan penambahan kolagen ikan komersil. Jurnal Teknologi Hasil Perikanan. 4(1):75-85.

Rasyid, A., 2002. Ekstraksi natrium alginat dari Turbinaria decurrens asal perairan Pulai Otangala (Sulawesi Utara). Seminar Nasional Rumput Laut Mini Simposium Mikroalgae dan Kongres 1 Ikatan Fikologi Indonesia. 23-25 Oktober 2002.

Renaud, S.M., Luong-Van, J.T., 2007. Seasonal variation in the chemical composition of tropical Australian marine macroalgae. Eigh Teen The International Seaweed Symposium. 1:155-61.

Saewan, N., Jimtaisong, A., 2013. Photoprotection of natural flavonoids. J. of Applied Pharmaceutical Science. 3(09): 129-141.

Sanger, G., 2010. Kandungan fosfor minuman sari rumput laut (Eucheuma cottonii). Pacific Journal. 1(5):792-795.

Sangi, M., Max, R.J.R., Henry, E.I.S., Veronica. M.A.M., 2008. Analisis fitokimia tumbuhan obat di Kabupaten Minahasa Utara. Journal Progres in Chemistry. 1(1):47-53.

Santoso, J., Yoshie, Y., Suzuki, T., 2014. The distribution and profile of nutrients and catechins of some Indonesia seaweeds. Fisheries Science. 68(2):1647-1648.

Sari, B.L., Susanti, N., Susanto., 2015. Skrining fitokimia dan aktivitas antioksidan fraksi etanol alga merah Eucheuma spinosum. Journal Pharmaceutical Sciences Research. 2(1):59-67.

Seenivasan, R., Rekha, M., Indu, H., Geetha, S., 2012. Antibacterial activity and phytochemical analysis of selected seaweeds from Mandapam Coast, India. Journal of Applied Pharmaceutical Science.2(10):159-169.
Selim, S.A., 2012. Antimicrobial, antiplasmid and cytotoxicity potentials of marine algae Halimedaopuntia and Sarconemafiliforme collected from red sea coast. World Academy ofScience. Journal Engineering and Technology. 2(1):1154-1159.

Septiana, A.T., Asnani, A., 2012. Kajian sifat fisikokimia ekstrak rumput laut coklat Sargassum duplicatum menggunakan berbagai pelarut dan metode ekstraksi. AGROINTEK. 6(1):22-28.

Soenardjo, N., 2011. Aplikasi budi daya rumput laut Eucheuma cottonii (weber van bosse) dengan metode jaring lepas dasar(net bag) model Cidaun. Buletin Oseanografi Marina. $1: 36-44$

Svobodova, A.,Psotova, J.; Walterova, D., 2003. Natural Phenolics in the Prevention of UVInduced Skin Damage. Biomed. Pap. 147:137-145.

Walters, C., Keeney, A., Wigal, CT., Johnston, CR., Cornelius, RD., 1997. Spectroscopy analysis and modelling of sunscreens. J. Chem. Educ. 2: 99-101,

Widyasanti, A., Rohdiana, D., Ekatama, N., 2016. Aktivitas antioksidan ekstrak teh putih (Camellia sinensis) dengan metode DPPH (2,2 difenil-1-pikrilhidrazil). PROTECH. $1(1): 1-9$.

Williams, A.M., 2007. Analysis of Benefits of Sargassum on Galveston Island and Indications for Beach Management Policy. [Thesis]. Graduate Studies of Texas A \& M University. Texas. USA.

Wilkinson, J.B., Moore, R.J., 1982. Harry's Cosmeticology (7thedition). New York: Chemical Publishing Company.

Wolf, R., Wolf, D., Morganti, P., Ruocco, V.. 2001. Sunscreens. J. Clinic. Dermatol. 19: 452459.

Wynne MJ. 2002. Turbinaria foliosa sp. nov. (Fucales, Phaeophyceae) from the Sultanate of Oman, with a census of currently recognized species in the genus Turbinaria. Phycological Research. 50:283293.

Yanuarti, R., Nurjanah, Anwar, E., Hidayat, T., 2017. Profil fenolik dan aktivitas antioksidan dari ekstrak rumput laut Turbinaria conoides dan Eucheuma cottonii. Jurnal Pengolahan Hasil Perikanan Indonesia. 20(2): 230-237. 